\title{
CD8+ T Cells in Multiple Sclerosis
}

\author{
Aleksandar Denic ${ }^{1}$, Bharath Wootla ${ }^{1}$, and Moses Rodriguez ${ }^{1,2,{ }^{*}}$ \\ ${ }^{1}$ Department of Neurology, Mayo Clinic, Rochester, MN 55905 \\ ${ }^{2}$ Department of Immunology, Mayo Clinic, Rochester, MN 55905
}

\section{Abstract}

Introduction- $\mathrm{CD} 8^{+} \mathrm{T}$ cells were originally considered to exert a suppressive role in demyelinating disease because of bias toward the $\mathrm{CD} 4^{+} \mathrm{T}$ cell-mediated experimental autoimmune encephalomyelitis, the most common MS model. However, recent studies of human MS lesion samples and CSF provided compelling evidence about the pathogenic role of CD $8^{+} \mathrm{T}$ cells. In this review, we discuss the theoretical roles of different $\mathrm{CD} 8^{+} \mathrm{T}$-cell subsets in MS.

Areas covered-A revised focus from $\mathrm{CD}^{+}$to $\mathrm{CD} 8^{+} \mathrm{T}$ cell-mediated demyelinating disease is summarized. Clonal expansion of $\mathrm{CD} 8^{+} \mathrm{T}$ cells in MS lesions and in vitro evidence that $\mathrm{CD} 8^{+} \mathrm{T}$ cells injure every CNS cell type and transect axons are discussed. The role of CD8 $8^{+} \mathrm{T}$ cells in two animal models of MS and of regulatory, IL-17-secreting $\mathrm{CD}^{+} \mathrm{T}$ cells is reviewed. Lastly, an overview about the pathogenic and/or beneficial role of various $\mathrm{CD} 8^{+} \mathrm{T}$-cell subsets is offered.

Expert opinion-Growing evidence supports the pathogenic role of $\mathrm{CD} 8^{+} \mathrm{T}$ cells. Clonally expanded CD8 ${ }^{+} \mathrm{T}$ cells within MS lesions may damage the nervous system. Revealing the specific antigen is critical to design novel efficient treatments with minimal adverse effects. Increasing evidence exists for the role of regulatory, IL-17-secreting CD8 ${ }^{+} \mathrm{T}$ cells in MS.

\section{Keywords}

Animal Models; CD8 ${ }^{+}$T cells; Central Nervous System; Clinical Trial; MHC Class I; Multiple Sclerosis; Regulatory T cells

\section{Introduction}

Multiple sclerosis (MS) is an inflammatory demyelinating disease of the central nervous system (CNS) with diversity of both clinical presentations and pathological features. It represents one of the most common causes of neurological disability in young adults in the western world. There is still no definitive cause of MS and no effective cure. Knowledge accumulated during the last few decades indicates that MS may be the consequence of a complex interaction of genetic predisposition and numerous environmental factors [1]. Regardless of the underlying cause, there is consensus that the the immune system is the major culprit in MS pathogenesis. Because experimental autoimmune encephalomyelitis (EAE), the most widely used mouse model of MS, is driven by Th- $1 \mathrm{CD} 4^{+} \mathrm{T}$ cells, this subset of $\mathrm{T}$ cells was the main area of MS research for several decades, whereas $\mathrm{CD} 8^{+} \mathrm{T}$ cells were neglected. Therefore, most knowledge about MS etiology, pathogenesis and therapeutic trials in human MS patients was based on the EAE studies. From the standpoint of understanding autoimmunity, immune surveillance, CNS inflammation and immunemediated tissue destruction, EAE has been very helpful. Results from EAE studies aided the

*Corresponding author: Moses Rodriguez, MD, Department of Neurology, Mayo Clinic, 200 First St. SW, Rochester, MN, 55905, Phone: (507) 284-4663, Fax: (507) 284-1086, Rodriguez.Moses@ mayo.edu. 
development of three approved medications for treatment in MS, glatiramer acetate, mitoxantrone and natalizumab. However, there were numerous ineffective or, in some cases, even harmful novel therapeutic trials based on EAE [2, 3]. In contrast to EAE, Theiler's murine encephalomyelitis virus (TMEV)-induced demyelinating disease emphasizes a role for $\mathrm{CD} 8^{+} \mathrm{T}$ cells in this animal model of MS depending on viral strain and the genetic of the experimental host [4-6]. More than two decades ago, Rodriguez et al. showed that TMEVmediated disease in mice can be abrogated by anti-CD8 treatment [7]. In addition, others showed that myelin-specific $\mathrm{CD} 8^{+} \mathrm{T}$ cells can induce severe autoimmune CNS disease in mice $[8,9]$.

$\mathrm{CD}^{+} \mathrm{T}$ cells and macrophages are present in human MS lesions $[10,11]$. However, the last 15 years of research have shifted the focus toward $\mathrm{CD} 8^{+} \mathrm{T}$ cells as evidence increasingly indicates this T-cell subtype as the major immune mediator of MS pathogenesis [12-14]. Recent neuropathologic studies convincingly demonstrated that $\mathrm{CD} 8^{+} \mathrm{T}$ cells predominate and outnumber $\mathrm{CD} 4^{+} \mathrm{T}$ cells in the inflammatory infiltrate in all MS lesions, regardless of disease stage $[15,16]$. Hoftberger et al. studied human autopsy material that included acute, chronic active MS, inactive MS and control cases. Using quantitative immunohistochemistry, this group discovered upregulated MHC class I expression on neurons, axons, astrocytes and oligodendrocytes in MS lesions, which correlated with disease severity and lesion activity [17]. This important study provided further evidence that cytotoxic $\mathrm{CD} 8^{+} \mathrm{T}$ cells may influence demyelination and/or axonal destruction in human MS lesions. In addition, the hypothesis that $\mathrm{CD} 4^{+} \mathrm{T}$ cells are primary culprits for pathogenic immune response in MS was seriously questioned when therapeutic depletion of this T-cell subtype did not show any therapeutic effect in MS patients [18]. Conversely, when all T cells were used as a therapeutic target, a significant reduction in MS relapses and development of new lesions was observed [19]. $\mathrm{CD}^{+} \mathrm{T}$ cells are generally known for their direct cytotoxic function; however, the recent growing body of literature suggests that this T-cell subtype also has a regulatory role in MS and contributes to suppressing disease progression and/or severity. Moreover, a novel subset of IL-17-secreting CD8 ${ }^{+} \mathrm{T}$ cells has been identified with a hypothesized role in worsening of MS. Genetic studies also contributed to the shift in thinking, as specific MHC class I alleles were found to have independent risk or protection from MS. These studies are consistent with the hypothesis that various $\mathrm{CD}^{+} \mathrm{T}$-cell subsets not only actively contribute to MS but also protect/limit the disease. Whereas interest in the role of $\mathrm{CD}^{+} \mathrm{T}$ cells in MS is a relatively new trend, these cells play an important role in other proven autoimmune diseases including rheumatoid arthritis, type 1 diabetes, autoimmune thyroiditis, vitiligo, and inflammatory bowel disease [20].

\section{CD8 ${ }^{+} \mathrm{T}$ Cells Are Present in MS Lesions}

Besides the long-standing focus on $\mathrm{CD} 4^{+} \mathrm{T}$ cells due to use of the EAE animal model, the other reason for minimal interest in the role of $\mathrm{CD} 8^{+} \mathrm{T}$ cells was the lack of CNS tissue samples from MS patients with acute lesions [21]. Another reason was the relative scarcity of immunocytochemistry materials needed to detect $\mathrm{CD} 8^{+} \mathrm{T}$ cells on formalin-fixed CNS tissues. In one of the first studies shifting focus toward the role of $\mathrm{CD} 8^{+} \mathrm{T}$ cells, Booss et al. found that $\mathrm{CD} 8^{+} \mathrm{T}$ cells outnumber the $\mathrm{CD} 4^{+} \mathrm{T}$-cell subset in all samples from MS patients, regardless of the MS subtype, duration and speed of disease progression [22]. Subsequently, Hauser et al. analyzed brains from 16 deceased progressive MS patients and 2 from acute MS. This group found that perivascular cuffs at the edges of active demyelinating plaques contained up to 50 times more $\mathrm{CD}^{+}$than $\mathrm{CD}^{+}{ }^{+} \mathrm{T}$ cells [23]. Moreover, $\mathrm{CD} 8^{+} \mathrm{T}$ cells predominated in occasional perivascular cuffs in the normal-appearing white matter (NAWM). None of the analyzed brains showed predominance of $\mathrm{CD}^{+}$over $\mathrm{CD} 8^{+} \mathrm{T}$ cells. 
There is clear evidence regarding the clonal expansion of $\mathrm{CD} 8^{+} \mathrm{T}$ cells in MS patients [24] and MS lesions [15], but the epitopes recognized by these $\mathrm{CD} 8^{+} \mathrm{T}$ cells remain elusive. Generally, peripheral blood contains approximately twice as many $\mathrm{CD} 4^{+} \mathrm{T}$ cells as $\mathrm{CD} 8^{+} \mathrm{T}$ cells. In a landmark study using single-cell polymerase chain reaction (PCR), Babbe et al. demonstrated that 1) $\mathrm{CD}^{+}$(not $\mathrm{CD}^{+}$) $\mathrm{T}$ cells predominated in all studied MS lesions; and 2) only a few $\mathrm{CD} 8^{+} \mathrm{T}$-cell clones were present in the infiltrate [15]. Interestingly, in one case, two $\mathrm{CD} 8^{+} \mathrm{T}$-cell clones were detected in the peripheral blood at two different time points following brain biopsy. In a later study, several expanded clones of $\mathrm{CD} 8^{+} \mathrm{T}$ cells were present not only in biopsied MS lesions but also in the cerebrospinal fluid (CSF) and blood [16]. An independent group from Germany analyzed CD4 ${ }^{+}$and $\mathrm{CD} 8^{+} \mathrm{T}$ cells isolated from the peripheral blood and CSF of $36 \mathrm{MS}$ patients for their T-cell receptor $\beta$-chain variability [25]. These authors also found significant expansion of CD8 ${ }^{+} \mathrm{T}$ cells in the CSF of most MS patients studied. Moreover, in selected patients, $\mathrm{CD}^{+} \mathrm{T}$-cell expansion proved stable over several months. More recently, another group from Germany analyzed distinct MS lesions and NAWM in whole-brain autopsy specimens from four MS patients [26]. Within each patient, the authors found identical T-cell clones in at least two distant brain regions, including MS lesions and NAWM, whereas some clones were present in all analyzed brain regions. Interestingly, these patients had some identical HLA class I and class II molecules, but the observed T-cell clones were unique for each individual patient. Unfortunately, no blood or CSF samples were available, so this study could not test for the presence of expanded T-cell clones in these compartments to confirm the previous findings by Skulina et al [16]. However, this study yielded an interesting observation with significance for future studies: the authors found silent nucleotide mutations in CDR3 regions of several T-cell receptor $\beta$-chains that did not disrupt amino acid sequence. After forming in thymus, the T-cell repertoire does not mutate when $\mathrm{T}$ cells become activated anywhere in the body. The presence of these silent nucleotide mutations indicated that the corresponding T-cell clones were not random bystander cells but, instead, were most likely stimulated by the particular antigen and selectively recruited and accumulated in the MS brain. Finally, Jilek et al. provided evidence that highly differentiated CD8 ${ }^{+} \mathrm{T}$ cells enrich the CSF in early MS rather than in primary progressive MS or "other neurological disorders" [27]. An independent Swedish study proposed that increased CD8 ${ }^{+}$T-cell cytotoxicity in the CSF (determined by increased granzyme levels) correlates with clinical relapses in MS patients with relapsing-remitting pattern of disease [28]. Granzyme levels were normal in control subjects and patients in remission.

In summary, the repeated and independent findings regarding the clonal expansion of CD8 ${ }^{+}$ $\mathrm{T}$ cells indicate antigen-specificity for discrete epitopes that are yet to be elucidated. Several candidate antigens recognized by these expanded $\mathrm{CD} 8^{+} \mathrm{T}$-cell clones include myelin antigens or viruses. Myelin-specific $\mathrm{CD}^{+} \mathrm{T}$ cells are encephalitogenic in mice and cause severe EAE disease [8]. Several viruses have been proposed as causative factors for MS, but so far none of these agents has been unequivocally linked to MS. One of the best candidates for a viral trigger of MS is the Epstein-Bar virus (EBV). However, despite extremely intriguing results, such as strong relationship between $\mathrm{EBV}$-specific $\mathrm{CD} 8^{+} \mathrm{T}$-cell response and early MS [29], the exact viral antigen that causes MS has been difficult to prove. Further studies need to elucidate whether EBV infection indeed predisposes one to MS or simply occurs due to the same susceptibility factors that eventually lead to MS. Another herpes-type virus associated with MS is neurotropic human herpes virus-6 (HHV-6) [30]. Indeed, significantly more $\mathrm{CD} 8^{+} \mathrm{T}$ cells directed against MBP and cross-reactive to HHV-6 residues were found in MS patients than in control subjects [31]. However, solid evidence that demonstrates a definite role for HHV-6 in causing MS is missing. 


\section{CD8+ T Cells Cause Damage to all CNS Cell Types}

Under normal conditions, $\mathrm{CD}^{+} \mathrm{T}$ cells are absent or extremely scarce in the CNS tissue [32]. Also, MHC class I molecules are normally only present in vascular and meningeal cells and poorly expressed on neurons and glia [33]. However, under inflammatory conditions, all CNS cells (astrocytes, oligodendrocytes, and neurons) express MHC Class I molecules and can be recognized and lysed by cytotoxic $\mathrm{CD} 8^{+} \mathrm{T}$ cells [17, 34](Figure 1). Medana et al. demonstrated that $\mathrm{CD} 8^{+} \mathrm{T}$ cells kill astrocytes primarily by fast perforinmediated lysis [35]. Others showed that MBP peptide-specific CD8 ${ }^{+} \mathrm{T}$ cells recognized and lysed oligodendrocytes in vitro without any exogenous antigen [36]. In addition, Pouly et al. demonstrated that treating oligodendrocytes with interferon- $\gamma($ IFN- $\gamma$ ) significantly upregulated expression of Fas (death receptor), which led to Fas-mediated apoptosis [37]. However, unlike astrocytes and oligodendrocytes, neurons possess some level of selective protection from $\mathrm{CD} 8^{+} \mathrm{T}$-cell attack by cytotoxic granules or TNF and related molecules [32]. It is controversial how cytotoxic T-lymphocytes (CTLs) kill neurons. An early in vitro study concluded that $\mathrm{CD} 8^{+} \mathrm{T}$ cells kill neurons via the perforin pathway instead of the Fas ligand-mediated pathway [38]. However, Medana et al. demonstrated the opposite; neurons resisted perforin-mediated lysis but succumbed to delayed Fas ligand-mediated apoptosis [35, 39]. The resistance to perforin-induced damage supports the finding by Khanna et al. in which $\mathrm{CD} 8^{+} \mathrm{T}$ cells use perforin to suppress infection without causing cytotoxicity in a mouse model of herpes simplex virus infection of sensory neurons [40]. Until that point, all in vitro experiments focused on CTL toxicity on neuronal bodies. But, due to lack of knowledge regarding $\mathrm{CD} 8^{+} \mathrm{T}$-cell effects on axons, the same group subsequently shifted focus. Using continuous visualization by confocal microscopy, the authors showed stable connections between $\mathrm{CD} 8^{+} \mathrm{T}$ cells and axons [41]. Following this, the first clues of axonal damage appeared within 15-20 minutes with further progression of injury, which ended in complete axonal transection within 55 minutes.

In pathological studies, Neumann et al. very nicely demonstrated close contact between $\mathrm{CD}^{+} \mathrm{T}$ cells and demyelinated axons in the human MS brain lesion as well as granzyme-B cytotoxic granules polarized towards the axons [32]. A similar observation was made in a tissue sample from Rasmussen's encephalitis in which cytotoxic granules of closely attached $\mathrm{CD} 8^{+} \mathrm{T}$ cells were polarized towards degenerating neurons [42]. By analyzing brain biopsies from 42 MS patients, Bitsch et al. showed a statistically significant, positive correlation between the number of $\mathrm{CD} 8^{+} \mathrm{T}$ cells and amyloid precursor protein (APP) expression, which is indicative of axonal damage [43]. The authors did not observe any correlation between $\mathrm{CD}^{+} \mathrm{T}$ cells and APP expression. In a subsequent study, the same group found a correlation between APP expression in MS lesions and duration and course of the disease [44]. Likewise, they confirmed the previous finding of a significant correlation between the number of $\mathrm{CD} 8^{+} \mathrm{T}$ cells and the extent of axon damage. A novel finding was that the highest APP expression was observed in acute MS lesions, within one year of disease onset. The clear implication of this finding is that neuroprotective therapy should commence as early as possible and be continuous [44]. This is consistent with the recent finding from our laboratory, where mice with virus-induced demyelinating disease that received early treatment with a single dose of the human neuron-binding antibody (rHIgM12) that protects axons had more beneficial effect than mice receiving treatment later in the disease course [45].

In summary, the aforementioned literature review about in vitro killing of CNS cells provides evidence that all brain cells are potentially targets for $\mathrm{CD} 8^{+} \mathrm{T}$ cell-mediated killing in MS. Nevertheless, differences were observed in cytotoxic mechanisms and susceptibility to lysis of various CNS cells. However, the reader should note that in vivo systems are much more complex and dependent on the combination of genetic factors and extent of CNS 
inflammation. Human MS is a pathologically heterogeneous disease with 4 distinct patterns of lesions $[46,47]$, and each distinct lesion type contains both $\mathrm{CD} 4^{+}$and $\mathrm{CD} 8^{+} \mathrm{T}$ cells along with different inflammatory cytokines and mediators. In the future, it will be important to elucidate the role(s) of each individual cell type present in these distinct lesions including CD8 ${ }^{+} \mathrm{T}$ cells.

\section{MHC Class I Genes Confer Risk or Protection from MS}

In order to perform their function, $\mathrm{CD} 8^{+} \mathrm{T}$ cells recognize and interact with antigens presented within major histocompatibility complex (MHC) class I molecules through their T-cell receptors (TCRs). In general, certain MHC class I alleles correlate with both susceptibility and protection from MS. In one of the earliest studies, HLA-A3 [48] and HLA-B7 [49] were most convincingly associated with MS. The association of HLA-A2, HLA-A7 and W10 antigens was less convincing, although it reached statistical significance [49]. Three decades later, using larger patient series, two studies showed that, independently of MHC class II antigens, HLA-A*0301 approximately doubles the risk of MS [50, 51]. In addition, both studies confirmed that the association of HLA-B7 (B*0702) was only secondary to MHC class II HLA-DR2 alleles and due to linkage disequilibrium with these alleles. Furthermore, these studies showed the protective function of a HLA-A*0201 allele, as the risk for developing MS was up to 50\% less. A more recent Swedish study confirmed protective properties of HLA-A $* 0201$ allele not explained by linkage disequilibrium with class II alleles [52]. Interestingly, HLA-A*0301 (risk) allele and HLA-A*0201 (protective) allele work in synergy with MHC class II allele DRB $1 * 1501$, which normally confers triple risk for developing MS (Table 1).

All of these genetic studies support the hypothesis that MHC class I alleles and, therefore, $\mathrm{CD} 8^{+} \mathrm{T}$ cells have important roles in MS that are both protective and pathogenic. Notably, MHC class I alleles can exert their effect independently from MHC class II alleles.

\section{CD8+ T Cells Induce Injury in Animal Models of MS}

\subsection{CD8 $+\mathrm{T}$ Cells Have a Role in Experimental Autoimmune Encephalomyelitis}

Because MS remains a disease with an unknown etiology and no effective cure, various animal models still provide the best way to study the mechanisms of immune-mediated pathology and test novel therapeutic strategies. As mentioned in the introduction, the two most commonly studied animal models of MS are experimental autoimmune encephalomyelitis (EAE) and Theiler's Murine Encephalomyelitis Virus (TMEV)-induced chronic demyelinating disease [53].

Generally, EAE studies have been historically biased towards CD4 ${ }^{+} \mathrm{T}$ cell, Th1-mediated pathology. This bias was corroborated by findings that $\mathrm{CD} 8^{+} \mathrm{T}$ cells have a regulatory role with only minimal effector functions $[54,55]$. However, since several groups repeatedly and independently demonstrated an important role for $\mathrm{CD}^{+} \mathrm{T}$ cells in MS pathogenesis, focus has shifted toward the role of this T-cell subset in the EAE animal model. In the first report,

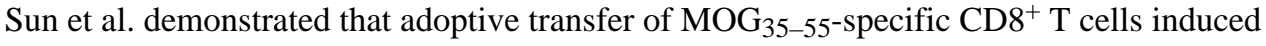
severe EAE disease in susceptible wild type C57BL/6 mice but not in isogeneic $\beta 2$ microglobulin $(\beta 2 \mathrm{~m})$-deficient mice [9]. Subsequently, by using series of truncated MOG peptides, Ford et al. revealed that $\mathrm{CD}^{+} \mathrm{T}$ cells specific for minimal epitope $\mathrm{MOG}_{37-46}$ induced EAE in C57BL/6 mice [56]. In another study, Huseby et al. used an MBP-primed model of EAE in $\mathrm{C} 3 \mathrm{H}$ mice to show that $\mathrm{MBP}_{79-87^{-}}$-specific $\mathrm{CD} 8^{+} \mathrm{T}$ cells induced pronounced CNS disease characterized by scattered but focal lesions surrounding small blood vessels [8]. Interestingly, these mice presented with ataxia, spasticity and brisk reflexes, symptoms that more closely mimic human MS than traditional EAE. To study in 
greater detail whether autoreactive $\mathrm{CD} 8^{+} \mathrm{T}$ cells cause significant loss of oligodendrocytes, Saxena et al. generated transgenic mice in which influenza virus hemagglutinin (HA) is selectively expressed in oligodendrocytes under MOG promoter [57]. Authors demonstrated that HA-specific, pre-activated $\mathrm{CD} 8^{+} \mathrm{T}$ cells induced inflammatory lesions in the spinal cord, brain and optic nerve in these transgenic animals. Pathologically, CNS lesions in these mice were very similar to an active human MS lesion, featuring $\mathrm{CD} 8^{+} \mathrm{T}$-cell infiltration, demyelination with axonal damage, focal loss of oligodendrocytes and microglia activation. This was the first EAE study to show in vivo $\mathrm{CD} 8^{+} \mathrm{T}$ cell-mediated oligodendrocytelysis. Using a more complex transgenic approach in which expression of cognate (self) antigen is restricted to oligodendrocytes, others proposed that myelin-specific $\mathrm{CD} 8^{+} \mathrm{T}$ cells also lead to axonal loss due to collateral bystander damage [58]. In addition, using confocal live imaging, these authors demonstrated $\mathrm{CD} 8^{+} \mathrm{T}$-cell migration through brain tissue. Finally, in a very recent study, Ji et al. demonstrated that "Tip-dendritic cells" cross-presented MHC Class I-restricted MBP epitopes and activated naïve CD8 ${ }^{+} \mathrm{T}$ cells, which then subsequently and specifically lyse oligodendrocytes [59]. This is consistent with the previously mentioned finding that MBP-specific $\mathrm{CD} 8^{+} \mathrm{T}$ cells are able to lyse human oligodendrocytes [36]. In summary, these recent studies provide new insights about the pathogenic role of $\mathrm{CD} 8^{+} \mathrm{T}$ cells on oligodendrocytes in the EAE model of MS.

\subsection{CD8 ${ }^{+} \mathrm{T}$ Cells Contribute to Axonal Injury and Demyelination in Virus-Induced Demyelinating Disease}

Compared to EAE, the involvement and contribution of $\mathrm{CD}^{+} \mathrm{T}$ cells in viral models of MS have been firmly established. In one of the first studies, Rodriguez et al. studied the individual contributions of $\mathrm{CD}^{+}$and $\mathrm{CD}^{+} \mathrm{T}$ cells on virus-induced demyelination and, as a secondary finding, observed that $\mathrm{CD} 8^{-/-}$mice on a susceptible haplotype presented with less severe clinical disease than $\mathrm{CD}^{-/-}$mice [60]. In the follow-up landmark study, RiveraQuinones et al. clearly demonstrated the pathogenic role of $\mathrm{CD}^{+} \mathrm{T}$ cells in promoting neurological deficits following demyelination [4]. This study was important because it challenged the concept that demyelination was sufficient to induce clinical deficits in TMEV-infected mice. However, authors observed that, despite equivalent levels of demyelination and inflammatory cell infiltration, only $\beta 2 \mathrm{~m}$-deficient mice, and not $\beta 2 \mathrm{~m}$ competent mice, presented with normal motor function as assessed by two independent functional assays and hind-limb motor-evoked potentials. In addition, this study proposed that $\beta 2 \mathrm{~m}$-deficient mice remained functionally normal due to relative preservation of axons and redistribution of sodium channels within axons. In contrast, the $\beta 2 \mathrm{~m}$-competent mice presented with degeneration and loss of axons, which likely resulted in significantly fewer sodium channels, disrupted pattern and severe motor decline. This study provided strong direct evidence that in virus-induced mouse model of MS, neurological and electrophysiological decline absolutely requires MHC Class I and $\mathrm{CD} 8^{+} \mathrm{T}$ cells (Figure 2). Furthermore, the finding regarding sodium channels supported a study that described altered distribution of these channels in human MS lesions [61]. Subsequently, Murray et al. showed that the mechanism of neurological injury is perforin-mediated [62] as perforindeficient mice presented with relative axonal protection and preserved motor function [5, 63]. As direct evidence that axons were preserved despite similar levels of demyelination, Ure et al. showed that $\beta 2 \mathrm{~m}$-deficient mice had up to 7 -fold higher numbers of retrogradelabeled brainstem neurons compared to control mice [64]. In another study, Johnson et al. used a model of fulminant and fatal demyelinating disease to test contribution of virus peptide-specific $\mathrm{CD} 8^{+} \mathrm{T}$ cells [65]. Normally, as a response to TMEV infection, mice on $\mathrm{H}-2^{b}$-resistant background mount a vigorous $\mathrm{CD} 8^{+} \mathrm{T}$-cell response against a single-virus capsid protein epitope, VP2 ${ }_{121-130}$ [66]. However, despite the presence of resistant $\mathrm{H}-2^{b}$ MHC haplotype, the infection of interferon- $\gamma$ receptor (IFN- $\gamma \mathrm{R}$ )-deficient mice leads to rapid demyelination and severe neurologic disease. One day prior to TMEV infection, 
authors treated these animals with VP2 $121-130$ or control E7 peptide to induce tolerance and eliminate specific $\mathrm{CD} 8^{+} \mathrm{T}$ cells. Removal of VP2 ${ }_{121}-130^{-}$-specific $\mathrm{CD} 8^{+} \mathrm{T}$ cells did not alter virus load or levels of demyelination but led to a significant preservation of motor function. Subsequently, using the same IFN- $\gamma$ R-deficient mice, authors demonstrated better motor performance in mice pretreated with VP2 $2_{121-130}$ peptide, due to relative preservation of retrograde axonal transport [67].

Since most observations about the pathogenic role of $\mathrm{CD} 8^{+} \mathrm{T}$ cells came from experiments in animals of the resistant black (BL) background, a recent attempt was made to determine the influence of $\beta 2 \mathrm{~m}$ deficiency on spinal cord pathology in mice with $\mathrm{H}-2^{q}$ haplotype on B10 background [6]. Several important observations were made: 1) demyelination was progressive in $\beta 2 \mathrm{~m}$-competent mice, whereas demyelination levels in $\beta 2 \mathrm{~m}$-deficient mice remained steady from 45 days up to a year post infection; 2) remyelination was minimal in $\beta 2 \mathrm{~m}$-competent mice and occurred very late in the disease, whereas remyelination was extensive in $\beta 2 \mathrm{~m}$-deficient mice; 3 ) due to marked differences in levels of demyelination and remyelination, axonal loss was more pronounced in $\beta 2 \mathrm{~m}$-competent mice. These findings indicate that, in addition to their axon-damaging role, $\mathrm{CD} 8^{+} \mathrm{T}$ cells can also be responsible for increased levels of demyelination and/or suppressed repair. The concept of a remyelination-inhibiting role for $\mathrm{CD}^{+} \mathrm{T}$ cells is not new $[68,69]$. On the other hand, because demyelination and modest axonal loss were evident in $\beta 2 \mathrm{~m}$-deficient mice, $\mathrm{CD} 8^{+} \mathrm{T}$ cells may not be the only mediators of the significant pathology observed in $\beta 2 \mathrm{~m}$-competent animals. This is supported by the study in which both T-cell subsets proved to have discrete contributions to demyelination [70]. In addition, the decreased burden of demyelination in $\beta 2 \mathrm{~m}$-deficient animals may, at least to some extent, be due to the absence of regulatory $\mathrm{CD} 8^{+} \mathrm{T}$ cells.

In summary, experiments in CD8-, CD4- and $\beta 2 \mathrm{~m}$-deficient mice provided strong evidence that demyelination and axonal damage followed by neurologic deficits are functionally separable. Apparently, demyelination creates an environment that favors the pathogenic role of $\mathrm{CD} 8^{+} \mathrm{T}$ cells in promoting axonal loss and the progression of neurological deficits.

\section{CD8 $+\mathrm{T}$ Cells as Regulatory Cells}

\section{1. $\mathrm{CD}^{+} \mathrm{T}$ Cells Have a Regulatory Role in Animal Models of MS}

Under normal conditions, regulatory $\mathrm{T}$ cells are necessary to maintain immunological tolerance to self-antigens and prevent disproportionate immune responses that are potentially deleterious to the host [71]. The two major functions of $\mathrm{CD} 8^{+} \mathrm{T}$ cells are cytotoxicity and suppression. Approximately two decades ago, two EAE studies supported the concept that regulatory/suppressive $\mathrm{CD}^{+} \mathrm{T}$ cells confer protection against disease relapses [54, 55]. It appears that the mechanism of $\mathrm{CD} 8^{+} \mathrm{T}$ cell-mediated suppression is related to Qa-1, a non-classical MHC class I molecule (mouse analog of human HLA-E) [72]. Madakamutil et al. demonstrated that expansion of regulatory $\mathrm{CD} 8^{+} \mathrm{T}$ cells induced apoptotic deletion of MBP-reactive $\mathrm{CD}^{+} \mathrm{T}$ cells that expressed VB8.2 T-cell receptor [73]. Experiments in Qa-1-deficient animals provided additional evidence. Hu et al. showed that Qa-1 is critical for immune regulation because Qa-1-deficient mice failed to prevent expansion of pathogenic, self-reactive $\mathrm{CD}^{+} \mathrm{T}$ cells, which therefore presented with severe PLP-mediated EAE [74]. Furthermore, another independent group revealed that antigenspecific $\mathrm{CD} 8^{+} / \mathrm{CD} 28^{-}$cells have the ability to suppress autoimmunity and prevent development of clinical deficits [75] (Table 2). Authors showed that adoptive transfer of $\mathrm{CD} 8^{+} / \mathrm{CD} 28^{-}$, but not $\mathrm{CD} 8^{+} / \mathrm{CD} 28^{+}$cells, into CD8-deficient mice led to a significant suppression of disease, and the mechanism of suppression required direct cell-to-cell contact with antigen-presenting cells (APCs). This supports the study in which naturally occurring $\mathrm{CD} 8^{+} / \mathrm{CD} 28^{-}$regulatory $\mathrm{T}$ cells prevented experimental inflammatory bowel disease in mice 
[76]. The important function of APCs in conferring protection from autoimmune disease involves CD40-ligand, immunosuppressive IL-10 [77] and transforming growth factor $\beta$ (TGF- $\beta$ ) [78]. More recently, Chen et al. revealed a new subset of CD8 ${ }^{+} \mathrm{T}$ cells that express latency-associated peptide (LAP) $\left(\mathrm{CD}^{+} / \mathrm{LAP}^{+} \mathrm{T}\right.$ cells $)$ and perform regulatory activity both in vivo and in vitro [79]. Utilizing IFN- $\gamma$ and TGF- $\beta$ these $\mathrm{CD}^{+} / \mathrm{LAP}^{+} \mathrm{T}$ cells ameliorated severity of clinical disease in EAE. A group from Japan proposed that $\mathrm{CD} 8^{+} / \mathrm{CD} 122^{+}$ regulatory $\mathrm{T}$ cells play an essential role during the recovery phase of EAE [80] because transferring these cells at the peak of EAE disease improved symptoms and depletion of these cells resulted in persistent clinical disease. Finally, Mangalam et al. further confirmed that $\mathrm{CD} 8^{+} / \mathrm{CD} 122^{+} \mathrm{T}$ cells function as regulatory cells, whereas $\mathrm{CD} 8^{+} / \mathrm{CD} 122^{-} \mathrm{T}$ cells have a pathogenic role [81]. It appears that $\mathrm{CD} 8^{+} / \mathrm{CD} 122^{+} \mathrm{T}$ cells modulate self-reactive $\mathrm{CD} 4^{+} \mathrm{T}$ cells through direct contact with APCs as well as through the release of IL-10, IFN $\gamma$ and TGF- $\beta$.

\subsection{CD8 ${ }^{+} \mathrm{T}$ Cells Have a Regulatory Role in Human MS}

Treating relapsing-remitting MS patients with glatiramer acetate (GA) has provided some understanding about the role of regulatory $\mathrm{CD} 8^{+} \mathrm{T}$ cells in human MS. It was hypothesized that glatiramer-specific Th2 cells enter the brain and, following cross-reactivity with myelin antigens, induce suppression and produce anti-inflammatory effects and subsequent beneficial effects in MS patients [82]. There is consensus that GA induces $\mathrm{CD} 8^{+} \mathrm{T}$-cell response[83] and that the up-regulation of regulatory $\mathrm{CD} 8^{+} \mathrm{T}$ cells, which suppress myelinspecific $\mathrm{CD}^{+}{ }^{+} \mathrm{T}$ cells by direct cytotoxic killing [84], accounts for the beneficial effects for MS patients. In a follow-up study, Biegler et al. demonstrated the existence of oligoclonal GA-specific $\mathrm{CD}^{+} \mathrm{T}$ cells, among which dominant clones persisted for a long time, whereas GA-specific $\mathrm{CD}^{+} \mathrm{T}$-cell responses were polyclonal and featured frequent evolution of their repertoire [85]. In addition, using quantitative real time PCR assays to assess functional evolution of $\mathrm{CD}^{+} \mathrm{T}$ cells, the authors observed up-regulation of several cytokines (Il-4, IL-5, IL-10 and TGF- $\beta$ ), which was indicative of regulatory phenotype. Another group discovered a new subset of regulatory $\mathrm{CD} 8^{+} \mathrm{T}$ cells that expresses HLA-G, has strong suppressive properties and may modulate inflammation thereby influencing the course of MS [86]. Indeed, Airas et al. demonstrated that a group of MS patients with increased postpartum disease activity had reduced numbers of both $\mathrm{CD} 4^{+}$and $\mathrm{CD} 8^{+} \mathrm{HLA}-\mathrm{G}-$ expressing T cells [87].

Correale et al. explored the potential effects of regulatory $\mathrm{CD} 8^{+} \mathrm{T}$ cells on MS development by analyzing CSF and peripheral blood of MS patients (in remission or during exacerbations) and healthy subjects [88]. Authors determined that both CSF and blood from patients with exacerbation contained less regulatory $\mathrm{CD} 8^{+} \mathrm{T}$ cells compared with patients in remission or controls. Apparently, increased expression of the CD94/NKG2A receptor limits the suppressive activity of the $\mathrm{CD} 8^{+} \mathrm{T}$ cells. More recently, the same group investigated the role of non-cytotoxic $\mathrm{CD} 8^{+} / \mathrm{CD} 25^{+} / \mathrm{FoxP}^{+}$cells during the course of human MS [89]. Similarly, authors analyzed peripheral blood, CSF and CD $8^{+} \mathrm{T}$-cell clones that recognize autoreactive $\mathrm{CD}^{+} \mathrm{T}$ cells in MS patients during exacerbation or remission, patients with other inflammatory neurological diseases and control healthy individuals. $\mathrm{CD} 8^{+} / \mathrm{CD} 25^{+} /$ FoxP $3^{+}$cells suppressed secretion of IFN- $\gamma$ and interleukin (IL)-17 and proliferation of autoreactive $\mathrm{CD}^{+}{ }^{+} \mathrm{T}$ cells. Interestingly, this suppression was abolished if FoxP3 was silenced by small interfering RNA. An important finding of this study was that the cloning frequency of regulatory $\mathrm{CD} 8^{+} \mathrm{T}$ cells was more suppressed in MS patients during exacerbations than in patients in remission or healthy controls. Therefore, it is clear that non-selective deletion of all $\mathrm{CD} 8^{+} \mathrm{T}$ cells, including subsets of regulatory $\mathrm{CD} 8^{+} \mathrm{T}$ cells, may aggravate MS. Following the conclusions of this work, an alternative approach may be to activate regulatory $\mathrm{CD} 8^{+} / \mathrm{CD} 25^{+} / \mathrm{FoxP}^{+}$cells, which may have a beneficial effect in 
human MS. In the most recent article, Hu et al. discovered a unique population of $\mathrm{CD}^{+} /$ CD161 $/{ }^{-} \mathrm{CD}^{2} 6^{+} \mathrm{T}$ cells in a normal human blood [90]. When activated, CD8 ${ }^{+} / \mathrm{CD} 161^{-} /$ $\mathrm{CD}^{+} 6^{+}$, but not $\mathrm{CD} 8^{+} / \mathrm{CD} 161^{-} / \mathrm{CD} 56^{-}$, subset was able to lyse TCR-activated CD $4^{+} \mathrm{T}$ cells in vitro. This novel regulatory $\mathrm{CD} 8^{+} \mathrm{T}$-cell subset will most likely be further explored in human MS in the hope of finding anothertherapeutic target to boost numbers of this subset. A short summary of regulatory CD8 ${ }^{+} \mathrm{T}$ cells in human MS appears in Table 3.

In summary, regulatory $\mathrm{CD} 8^{+} \mathrm{T}$ cells may exert their role in disease/inflammation suppression either by direct killing of self-reactive $\mathrm{CD}^{+} \mathrm{T}$ cells or indirectly through APCs (Figure 3).

\section{CD8+ T Cells Make IL-17, which may Cause Damage in MS Lesions}

Recently, there has been increased interest in the potential role of interleukin (IL)-17 in MS lesions. Compared to classic cytotoxic CD8 ${ }^{+} \mathrm{T}$ cells, IL-17-secreting CD8 ${ }^{+} \mathrm{T}$ cells (Tc-17) have much less cytotoxic functions, mainly because levels of the T-box transcription factor Eomesodermin, IFN- $\gamma$, and granzyme B are significantly reduced [91]. Initially, because of convincing results from EAE studies, $\mathrm{CD} 4^{+} \mathrm{T}$ cells were considered to be the main source of IL-17 [92, 93]. Elevated numbers of IL-17-producing mononuclear cells have been detected in peripheral blood of MS patients, especially during exacerbations [94]. The proportion of these IL-17-producing cells was higher in the CSF. However, Tzartos et al. were the first to provide evidence that $\mathrm{CD} 4^{+}$and $\mathrm{CD} 8^{+} \mathrm{T}$ cells secreted IL-17 in equivalent amounts in active MS lesions [95]. Indeed, Vanden Eijnden et al. demonstrated that in cultured human cells, IL-23 had a greater influence on polarizing naïve $\mathrm{CD} 8^{+} \mathrm{T}$ cells rather than $\mathrm{CD} 4^{+} \mathrm{T}$ cells into IL-17-secreting cells [96]. Subsequently, Tc-17 cells were assessed in peripheral blood and CSF of early MS patients and control group. Interestingly, the authors observed increased numbers of these cells in the CSF of early MS patients but not in peripheral blood. In peripheral blood from healthy human individuals, only CD4 ${ }^{+} \mathrm{T}$ cells produced IL-17 [97]. It appears that the inflammatory microenvironment of the human brain and the clonal expansion of $\mathrm{CD}^{+} \mathrm{T}$ cells in the disease setting initiate production of IL-17 [95]. Several pieces of evidence support this hypothesis. One is the presence of IL-23, a cytokine produced by macrophages and dendritic cells in MS lesions [98]. Additionally, a recent study suggests that pro-inflammatory cytokines IL- 6 and IL- $1 \beta$ also polarize naïve T cells into IL-17-secreting cells [99]. Another group demonstrated that almost all circulating Tc-17 cells belonged to a subset of non-cytotoxic, pro-inflammatory CD $161^{\text {high }} \mathrm{CCR}^{+} \mathrm{CD} 8^{+} \mathrm{T}$ cells [100]. Authors further showed that these $\mathrm{CD} 161^{\text {high }} \mathrm{CCR}^{+} \mathrm{CD} 8^{+} \mathrm{T}$ cells comprised approximately $10 \%$ of all $\mathrm{CD} 8^{+} \mathrm{T}$ cells detected in analyzed MS lesions but were not detectable in brain samples from a control subject who passed away from cardiac arrest. Interestingly, coexisting expression of chemokine receptor 6 (CCR6) implies that these cells migrate to the brain parenchyma [101]. Together, these findings provide evidence about the pathogenic role of $\mathrm{CD} 161^{\text {high }} \mathrm{CCR} 6^{+} \mathrm{CD} 8^{+} \mathrm{T}$ cells in human MS.

In summary, it is likely that Tc-17 cells contribute to human MS and contribute to worsening disease, since significant numbers of these cells appear in human MS lesions during exacerbations. Clearly, a more specific definition of IL-17-secreting CD8 ${ }^{+} \mathrm{T}$ cells represents an avenue for future research and, ideally, a new therapeutic target(s) on this CD8 ${ }^{+}$T-cell subtype.

\section{Expert Opinion}

Historically, most conclusions about human MS pathogenesis were based on results from $\mathrm{CD}^{+}$Th1 T cell-mediated EAE studies, and therefore, numerous therapeutic strategies have been developed to influence the activity of this T-cell subset. Many treatments effective in 
EAE were ineffective or, paradoxically, even worsened clinical disease in MS patients. The growing body of research implicating $\mathrm{CD} 8^{+} \mathrm{T}$ cells in MS pathogenesis may explain the failure of many EAE-based therapies. In addition, recent clinical trials with various monoclonal antibodies confirm previously discussed neuropathological data implicating $\mathrm{CD}^{+} \mathrm{T}$ cells in MS $[18,19,102,103]$.

We propose that both $\mathrm{CD} 4^{+}$and $\mathrm{CD} 8^{+} \mathrm{T}$ cells have pathogenic or beneficial (regulatory/ suppressive) functions in MS pathogenesis. To some extent, both functions may exist simultaneously. Recent literature indicates that $\mathrm{CD} 8^{+} \mathrm{T}$ cells are critical in MS pathogenesis. This does not diminish the role of $\mathrm{CD}^{+} \mathrm{T}$ cells or even $\mathrm{B}$ cells, which may be important in keeping $\mathrm{CD} 8^{+} \mathrm{T}$ cells continuously activated [104]. Several pieces of evidence support the hypothesis that $\mathrm{CD} 8^{+} \mathrm{T}$ cells are pathogenic: 1) clonal expansion and multifold increase of $\mathrm{CD} 8^{+} \mathrm{T}$ cells in acute and chronic MS lesions as compared to $\mathrm{CD}^{+} \mathrm{T}$ cells [15]; 2) upregulation of cytotoxic mediator granzyme B in MS [28, 32]; 3) killing of neurons, transection of axons and the correlation of number of $\mathrm{CD} 8^{+} \mathrm{T}$ cells with the degree of axonal injury $[32,43]$; 4) clonal expansion of $\mathrm{CD}^{+} \mathrm{T}$ cells, but not $\mathrm{CD} 4^{+} \mathrm{T}$ cells, evident in CSF and blood of MS patients [16, 25]; 5) higher prevalence of CNS-specific CD8 ${ }^{+} \mathrm{T}$ cells in MS patients versus healthy individuals $[105,106]$; and 6) non-specific targeting of all T cells in clinical trials is beneficial in MS patients, whereas targeting only the CD4 ${ }^{+} \mathrm{T}$-cell subset was ineffective. In addition, there is increasing evidence for the role of regulatory/ suppressor $\mathrm{CD}^{+} \mathrm{T}$ cells, as this subset was significantly decreased in both CSF and blood in patients with exacerbated MS vs. patients in remission or controls [88]. Genetic evidence for this is MHC class I gene HLA-A2 (A*0201); it confers protection against disease, which implies that some $\mathrm{CD} 8^{+} \mathrm{T}$ cells may indeed be beneficial, whereas others are pathogenic (HLA-A3 (A*0301)). Finally, IL17-secreting CD8 ${ }^{+} \mathrm{T}$ cells shed new light on the MS pathogenesis $[95,97]$. Apparently, cytotoxic and regulatory subsets of $\mathrm{CD} 8^{+} \mathrm{T}$ cells, along with $\mathrm{CD} 4^{+} \mathrm{T}$ cells, have a complex role in MS pathogenesis, and this disrupted balance may shift the disease towards remission or exacerbation. This complex interaction of immune cells with emphasis on the role of $\mathrm{CD} 8^{+} \mathrm{T}$ cells from unknown trigger to CNS injury is summarized in Figure 4. It is critical to continue investigating various $\mathrm{CD}^{+} \mathrm{T}$-cell subsets to reveal their role and monitor their levels during the course of the disease. In addition, it is important to elucidate further the interactions of different T-cell subsets with each other as well as with neurons and glia in the CNS. Lastly, it is critical to determine the 9 amino-acid peptide sequence recognized by $\mathrm{CD} 8^{+} \mathrm{T}$ cells in the CNS of MS patients.

The clonal expansion of $\mathrm{CD}^{+} \mathrm{T}$ cells with apparent skewing of the CDR3 junctional regions in MS lesions is clearly established, and thus, it is extremely unlikely that these cells are just bystanders. Even though many recent studies clearly implicate $\mathrm{CD} 8^{+} \mathrm{T}$ cells in MS pathogenesis, the neurotoxicity-triggering antigen, whether it is component of a myelin, other auto-antigen or exogenous pathogen (virus), is still elusive. A possible approach to investigate specificity of clonally expanded $\mathrm{CD} 8^{+} \mathrm{T}$ cells in CSF and/or blood is to challenge them with a series of candidate antigens, as well as combinatorial peptide libraries [107]. Revealing this elusive antigen may allow targeting of only epitope-specific CD ${ }^{+} \mathrm{T}$ cells, as we showed previously in animal model of MS [65]. Removal of only epitopespecific $\mathrm{CD}^{+} \mathrm{T}$ cells may prevent further progression of MS and would also preserve the other $\mathrm{CD} 8^{+} \mathrm{T}$ cells required for protective immunity. This should eliminate the risk of opportunistic infections due to the non-selective blockade of all T cells such as PML in some of natalizumab-treated MS patients [108].

Finally, there is increased evidence that regulatory $\mathrm{CD} 8^{+} \mathrm{T}$ cells control MS. Research in this area is rapidly expanding and will hopefully bring novel molecular candidates to enhance this T-cell subset, which may be a successful therapy in human MS. In addition, given the recent insights about the possible role of IL-17-secreting $\mathrm{CD} 8^{+} \mathrm{T}$ cells (Tc-17) in 
early MS or during MS exacerbations, anti-IL-17 monoclonal antibodies may also treat MS. However, researchers will need to investigate and define the Tc-17 cell subset in detail to reveal its mechanism of action and identify potential therapeutic targets.

\section{Acknowledgments}

Financial Support

This work was supported by grants from the NIH (R01 GM092993, R01 NS048357 and R21 NS073684) and the National Multiple Sclerosis Society (CA 1060A). This work was also supported by a High-Impact Pilot and Feasibility Award (HIPFA) and Novel Methodology Award (NMDA) from the Mayo Clinic Center for Translational Science Activities (CTSA) and Mayo Clinic CTSA grant number UL1 TR000135 from the National Center for Advancing Translational Science (NCATS), a component of the National Institutes of Health (NIH). We also acknowledge with thanks support from the Applebaum, Hilton, Peterson and Sanford Foundations, the Minnesota Partnership Award for Biotechnology and Medical Genomics and the McNeilus family.

\section{References}

$*$ of interest

** of considerable interest

1. Noseworthy JH, Lucchinetti C, Rodriguez M, et al. Multiple sclerosis. N Engl J Med. 2000; 343:938-52. [PubMed: 11006371]

2. Kappos L, Comi G, Panitch H, et al. Induction of a non-encephalitogenic type $2 \mathrm{~T}$ helper-cell autoimmune response in multiple sclerosis after administration of an altered peptide ligand in a placebo-controlled, randomized phase II trial. The Altered Peptide Ligand in Relapsing MS Study Group. Nat Med. 2000; 6:1176-82. [PubMed: 11017151]

3. Bielekova B, Goodwin B, Richert N, et al. Encephalitogenic potential of the myelin basic protein peptide (amino acids 83-99) in multiple sclerosis: results of a phase II clinical trial with an altered peptide ligand. Nat Med. 2000; 6:1167-75. [PubMed: 11017150]

4**. Rivera-Quinones C, McGavern D, Schmelzer JD, et al. Absence of neurological deficits following extensive demyelination in a class I-deficient murine model of multiple sclerosis. Nat Med. 1998; 4:187-93. Important study that clearly implicates CD8 ${ }^{+} \mathrm{T}$ cells as pathogenic, leading to axonal loss and clinical deficits in a murine model of demyelination. [PubMed: 9461192]

5. Howe CL, Adelson JD, Rodriguez M. Absence of perforin expression confers axonal protection despite demyelination. Neurobiol Dis. 2007; 25:354-9. [PubMed: 17112732]

6. Denic A, Pirko I, Wootla B, et al. Deletion of beta-2-microglobulin ameliorates spinal cord lesion load and promotes recovery of brainstem NAA levels in a murine model of multiple sclerosis. Brain Pathol. 2012; 22:698-708. [PubMed: 22335434]

7. Rodriguez M, Sriram S. Successful therapy of Theiler's virus-induced demyelination (DA strain) with monoclonal anti-Lyt-2 antibody. J Immunol. 1988; 140:2950-5. [PubMed: 2966203]

8. Huseby ES, Liggitt D, Brabb T, et al. A pathogenic role for myelin-specific CD8(+) T cells in a model for multiple sclerosis. J Exp Med. 2001; 194:669-76. [PubMed: 11535634]

9. Sun D, Whitaker JN, Huang Z, et al. Myelin antigen-specific CD8+ T cells are encephalitogenic and produce severe disease in C57BL/6 mice. J Immunol. 2001; 166:7579-87. [PubMed: 11390514]

10. Markovic-Plese S, McFarland HF. Immunopathogenesis of the multiple sclerosis lesion. Curr Neurol Neurosci Rep. 2001; 1:257-62. [PubMed: 11898527]

11. Weiner HL. Multiple sclerosis is an inflammatory T-cell-mediated autoimmune disease. Arch Neurol. 2004; 61:1613-5. [PubMed: 15477521]

12. Friese MA, Fugger L. Autoreactive CD8+ T cells in multiple sclerosis: a new target for therapy? Brain. 2005; 128:1747-63. [PubMed: 15975943]

13. Goverman J, Perchellet A, Huseby ES. The role of CD8(+) T cells in multiple sclerosis and its animal models. Curr Drug Targets Inflamm Allergy. 2005; 4:239-45. [PubMed: 15853746] 
14. Lassmann H, Ransohoff RM. The CD4-Th1 model for multiple sclerosis: a critical [correction of crucial] re-appraisal. Trends Immunol. 2004; 25:132-7. [PubMed: 15036040]

15**. Babbe H, Roers A, Waisman A, et al. Clonal expansions of CD8(+) T cells dominate the T cell infiltrate in active multiple sclerosis lesions as shown by micromanipulation and single cell polymerase chain reaction. J Exp Med. 2000; 192:393-404. One of the first studies to demonstrate clonal expansion and dominance of $\mathrm{CD}^{+} \mathrm{T}$ cells in the CSF of patients with early MS. [PubMed: 10934227]

16. Skulina C, Schmidt S, Dornmair K, et al. Multiple sclerosis: brain-infiltrating CD8+ T cells persist as clonal expansions in the cerebrospinal fluid and blood. Proc Natl Acad Sci U S A. 2004; 101:2428-33. [PubMed: 14983026]

17*. Hoftberger R, Aboul-Enein F, Brueck W, et al. Expression of major histocompatibility complex class I molecules on the different cell types in multiple sclerosis lesions. Brain Pathol. 2004; 14:43-50. Important study demonstrating up-regulation of MHC Class I on all CNS cell types dependent on severity of disease and lesion activity. [PubMed: 14997936]

18. van Oosten BW, Lai M, Hodgkinson S, et al. Treatment of multiple sclerosis with the monoclonal anti-CD4 antibody cM-T412: results of a randomized, double-blind, placebo-controlled, MRmonitored phase II trial. Neurology. 1997; 49:351-7. [PubMed: 9270561]

19. Coles AJ, Compston DA, Selmaj KW, et al. Alemtuzumab vs. interferon beta-1a in early multiple sclerosis. N Engl J Med. 2008; 359:1786-801. [PubMed: 18946064]

20. Liblau RS, Wong FS, Mars LT, et al. Autoreactive CD8 T cells in organ-specific autoimmunity: emerging targets for therapeutic intervention. Immunity. 2002; 17:1-6. [PubMed: 12150886]

$21 *$ Johnson AJ, Suidan GL, McDole J, et al. The CD8 T cell in multiple sclerosis: suppressor cell or mediator of neuropathology? Int Rev Neurobiol. 2007; 79:73-97. First study to show that removal of virus peptide-specific $\mathrm{CD}^{+} \mathrm{T}$ cells led to preservation of motor function. [PubMed: 17531838]

22. Booss J, Esiri MM, Tourtellotte WW, et al. Immunohistological analysis of T lymphocyte subsets in the central nervous system in chronic progressive multiple sclerosis. J Neurol Sci. 1983; 62:219-32. [PubMed: 6607973]

23. Hauser SL, Bhan AK, Gilles F, et al. Immunohistochemical analysis of the cellular infiltrate in multiple sclerosis lesions. Ann Neurol. 1986; 19:578-87. [PubMed: 3524414]

24. Monteiro J, Hingorani R, Pergolizzi R, et al. Clonal dominance of CD8+ T-cell in multiple sclerosis. Ann N Y Acad Sci. 1995; 756:310-2. [PubMed: 7645848]

25. Jacobsen M, Cepok S, Quak E, et al. Oligoclonal expansion of memory CD8+ T cells in cerebrospinal fluid from multiple sclerosis patients. Brain. 2002; 125:538-50. [PubMed: 11872611]

26. Junker A, Ivanidze J, Malotka J, et al. Multiple sclerosis: T-cell receptor expression in distinct brain regions. Brain. 2007; 130:2789-99. [PubMed: 17890278]

27. Jilek S, Schluep M, Rossetti AO, et al. CSF enrichment of highly differentiated CD8+ T cells in early multiple sclerosis. Clin Immunol. 2007; 123:105-13. [PubMed: 17188575]

28. Malmestrom C, Lycke J, Haghighi S, et al. Relapses in multiple sclerosis are associated with increased CD8+ T-cell mediated cytotoxicity in CSF. J Neuroimmunol. 2008; 196:159-65. [PubMed: 18396337]

29. Jilek S, Schluep M, Meylan P, et al. Strong EBV-specific CD8+ T-cell response in patients with early multiple sclerosis. Brain. 2008; 131:1712-21. [PubMed: 18550621]

30. Fotheringham J, Jacobson S. Human herpesvirus 6 and multiple sclerosis: potential mechanisms for virus-induced disease. Herpes. 2005; 12:4-9. [PubMed: 16026638]

31. Cheng W, Ma Y, Gong F, et al. Cross-reactivity of autoreactive T cells with MBP and viral antigens in patients with MS. Front Biosci. 2012; 17:1648-58.

32. Neumann H, Medana IM, Bauer J, et al. Cytotoxic T lymphocytes in autoimmune and degenerative CNS diseases. Trends Neurosci. 2002; 25:313-9. [PubMed: 12086750]

33. Huseby ES, Huseby PG, Shah S, et al. Pathogenic CD8 T cells in multiple sclerosis and its experimental models. Front Immunol. 2012; 3:64. [PubMed: 22566945]

34. Neumann H, Cavalie A, Jenne DE, et al. Induction of MHC class I genes in neurons. Science. 1995; 269:549-52. [PubMed: 7624779] 
35. Medana I, Li Z, Flugel A, et al. Fas ligand (CD95L) protects neurons against perforin-mediated T lymphocyte cytotoxicity. J Immunol. 2001; 167:674-81. [PubMed: 11441070]

36. Jurewicz A, Biddison WE, Antel JP. MHC class I-restricted lysis of human oligodendrocytes by myelin basic protein peptide-specific CD8 T lymphocytes. J Immunol. 1998; 160:3056-9. [PubMed: 9510211]

37. Pouly S, Becher B, Blain M, et al. Interferon-gamma modulates human oligodendrocyte susceptibility to Fas-mediated apoptosis. J Neuropathol Exp Neurol. 2000; 59:280-6. [PubMed: 10759183]

38. Rensing-Ehl A, Malipiero U, Irmler M, et al. Neurons induced to express major histocompatibility complex class I antigen are killed via the perforin and not the Fas (APO-1/CD95) pathway. Eur J Immunol. 1996; 26:2271-4. [PubMed: 8814277]

39. Medana IM, Gallimore A, Oxenius A, et al. MHC class I-restricted killing of neurons by virusspecific CD8+ T lymphocytes is effected through the Fas/FasL, but not the perforin pathway. Eur J Immunol. 2000; 30:3623-33. [PubMed: 11169405]

40. Khanna KM, Bonneau RH, Kinchington PR, et al. Herpes simplex virus-specific memory CD8+ T cells are selectively activated and retained in latently infected sensory ganglia. Immunity. 2003; 18:593-603. [PubMed: 12753737]

41. Medana I, Martinic MA, Wekerle H, et al. Transection of major histocompatibility complex class I-induced neurites by cytotoxic T lymphocytes. Am J Pathol. 2001; 159:809-15. [PubMed: 11549572]

42. Bien CG, Bauer J, Deckwerth TL, et al. Destruction of neurons by cytotoxic T cells: a new pathogenic mechanism in Rasmussen's encephalitis. Ann Neurol. 2002; 51:311-8. [PubMed: 11891826]

43. Bitsch A, Schuchardt J, Bunkowski S, et al. Acute axonal injury in multiple sclerosis. Correlation with demyelination and inflammation Brain. 2000; 123 (Pt 6):1174-83.

44. Kuhlmann T, Lingfeld G, Bitsch A, et al. Acute axonal damage in multiple sclerosis is most extensive in early disease stages and decreases over time. Brain. 2002; 125:2202-12. [PubMed: 12244078]

45. Denic A, Macura SI, Warrington AE, et al. A single dose of neuron-binding human monoclonal antibody improves spontaneous activity in a murine model of demyelination. PLoS One. 2011; 6:e26001. [PubMed: 22022490]

46. Lucchinetti CF, Bruck W, Lassmann H. Evidence for pathogenic heterogeneity in multiple sclerosis. Ann Neurol. 2004; 56:308. [PubMed: 15293289]

47. Lucchinetti C, Bruck W, Parisi J, et al. Heterogeneity of multiple sclerosis lesions: implications for the pathogenesis of demyelination. Ann Neurol. 2000; 47:707-17. [PubMed: 10852536]

48. Naito S, Namerow N, Mickey MR, et al. Multiple sclerosis: association with HL-A3. Tissue Antigens. 1972; 2:1-4. [PubMed: 5077731]

49. Jersild C, Svejgaard A, Fog T. HL-A antigens and multiple sclerosis. Lancet. 1972; 1:1240-1. [PubMed: 4113225]

50. Fogdell-Hahn A, Ligers A, Gronning M, et al. Multiple sclerosis: a modifying influence of HLA class I genes in an HLA class II associated autoimmune disease. Tissue Antigens. 2000; 55:140-8. [PubMed: 10746785]

51. Harbo HF, Lie BA, Sawcer S, et al. Genes in the HLA class I region may contribute to the HLA class II-associated genetic susceptibility to multiple sclerosis. Tissue Antigens. 2004; 63:237-47. [PubMed: 14989713]

52. Brynedal B, Duvefelt K, Jonasdottir G, et al. HLA-A confers an HLA-DRB1 independent influence on the risk of multiple sclerosis. PLoS One. 2007; 2:e664. [PubMed: 17653284]

53. Denic A, Johnson AJ, Bieber AJ, et al. The relevance of animal models in multiple sclerosis research. Pathophysiology. 2011; 18:21-9. [PubMed: 20537877]

54. Jiang H, Zhang SI, Pernis B. Role of CD8+ T cells in murine experimental allergic encephalomyelitis. Science. 1992; 256:1213-5. [PubMed: 1375398]

55. Koh DR, Fung-Leung WP, Ho A, et al. Less mortality but more relapses in experimental allergic encephalomyelitis in CD8-/- mice. Science. 1992; 256:1210-3. [PubMed: 1589800] 
56. Ford ML, Evavold BD. Specificity, magnitude, and kinetics of MOG-specific CD8+ T cell responses during experimental autoimmune encephalomyelitis. Eur J Immunol. 2005; 35:76-85. [PubMed: 15593305]

57. Saxena A, Bauer J, Scheikl T, et al. Cutting edge: Multiple sclerosis-like lesions induced by effector CD8 T cells recognizing a sequestered antigen on oligodendrocytes. J Immunol. 2008; 181:1617-21. [PubMed: 18641296]

58. Sobottka B, Harrer MD, Ziegler U, et al. Collateral bystander damage by myelin-directed CD8+ T cells causes axonal loss. Am J Pathol. 2009; 175:1160-6. [PubMed: 19700745]

59. Ji Q, Castelli L, Goverman JM. MHC class I-restricted myelin epitopes are cross-presented by TipDCs that promote determinant spreading to CD8(+) T cells. Nat Immunol. 2013; 14:254-61. [PubMed: 23291597]

60. Rodriguez M, Rivera-Quinones C, Murray PD, et al. The role of CD4+ and CD8+ T cells in demyelinating disease following Theiler's virus infection: a model for multiple sclerosis. J Neurovirol. 1997; 3 (Suppl 1):S43-5. [PubMed: 9179791]

61. Moll C, Mourre C, Lazdunski M, et al. Increase of sodium channels in demyelinated lesions of multiple sclerosis. Brain Res. 1991; 556:311-6. [PubMed: 1657307]

62. Murray PD, McGavern DB, Lin X, et al. Perforin-dependent neurologic injury in a viral model of multiple sclerosis. J Neurosci. 1998; 18:7306-14. [PubMed: 9736651]

63. Deb C, Lafrance-Corey RG, Zoecklein L, et al. Demyelinated axons and motor function are protected by genetic deletion of perforin in a mouse model of multiple sclerosis. J Neuropathol Exp Neurol. 2009; 68:1037-48. [PubMed: 19680139]

64. Ure DR, Rodriguez M. Preservation of neurologic function during inflammatory demyelination correlates with axon sparing in a mouse model of multiple sclerosis. Neuroscience. 2002; 111:399-411. [PubMed: 11983325]

65. Johnson AJ, Upshaw J, Pavelko KD, et al. Preservation of motor function by inhibition of CD8+ virus peptide-specific T cells in Theiler's virus infection. Faseb J. 2001; 15:2760-2. [PubMed: 11606479]

66. Johnson AJ, Njenga MK, Hansen MJ, et al. Prevalent class I-restricted T-cell response to the Theiler's virus epitope Db:VP2121-130 in the absence of endogenous CD4 help, tumor necrosis factor alpha, gamma interferon, perforin, or costimulation through CD28. J Virol. 1999; 73:37028. [PubMed: 10196262]

67. Howe CL, Ure D, Adelson JD, et al. CD8+ T cells directed against a viral peptide contribute to loss of motor function by disrupting axonal transport in a viral model of fulminant demyelination. J Neuroimmunol. 2007; 188:13-21. [PubMed: 17493690]

68. Rodriguez M, Lindsley MD. Immunosuppression promotes CNS remyelination in chronic virusinduced demyelinating disease. Neurology. 1992; 42:348-57. [PubMed: 1736164]

69. Miller DJ, Rivera-Quinones C, Njenga MK, et al. Spontaneous CNS remyelination in beta 2 microglobulin-deficient mice following virus-induced demyelination. J Neurosci. 1995; 15:834552. [PubMed: 8613767]

70. Murray PD, Pavelko KD, Leibowitz J, et al. CD4(+) and CD8(+) T cells make discrete contributions to demyelination and neurologic disease in a viral model of multiple sclerosis. $\mathrm{J}$ Virol. 1998; 72:7320-9. [PubMed: 9696828]

71. Sakaguchi S, Yamaguchi T, Nomura T, et al. Regulatory T cells and immune tolerance. Cell. 2008; 133:775-87. [PubMed: 18510923]

72. Kumar V. Homeostatic control of immunity by TCR peptide-specific Tregs. J Clin Invest. 2004; 114:1222-6. [PubMed: 15520851]

73. Madakamutil LT, Maricic I, Sercarz E, et al. Regulatory T cells control autoimmunity in vivo by inducing apoptotic depletion of activated pathogenic lymphocytes. J Immunol. 2003; 170:298592. [PubMed: 12626551]

74. Hu D, Ikizawa K, Lu L, et al. Analysis of regulatory CD8 T cells in Qa-1-deficient mice. Nat Immunol. 2004; 5:516-23. [PubMed: 15098030]

75. Najafian N, Chitnis T, Salama AD, et al. Regulatory functions of CD8+CD28- T cells in an autoimmune disease model. J Clin Invest. 2003; 112:1037-48. [PubMed: 14523041] 
76. Menager-Marcq I, Pomie C, Romagnoli P, et al. CD8+CD28- regulatory T lymphocytes prevent experimental inflammatory bowel disease in mice. Gastroenterology. 2006; 131:1775-85. [PubMed: 17087950]

77. Gilliet M, Liu YJ. Generation of human CD8 T regulatory cells by CD40 ligand-activated plasmacytoid dendritic cells. J Exp Med. 2002; 195:695-704. [PubMed: 11901196]

78. Faunce DE, Terajewicz A, Stein-Streilein J. Cutting edge: in vitro-generated tolerogenic APC induce CD8+ T regulatory cells that can suppress ongoing experimental autoimmune encephalomyelitis. J Immunol. 2004; 172:1991-5. [PubMed: 14764660]

79. Chen ML, Yan BS, Kozoriz D, et al. Novel CD8+ Treg suppress EAE by TGF-beta- and IFNgamma-dependent mechanisms. Eur J Immunol. 2009; 39:3423-35. [PubMed: 19768696]

80*. Lee YH, Ishida Y, Rifa'i M, et al. Essential role of CD8+CD122+ regulatory T cells in the recovery from experimental autoimmune encephalomyelitis. J Immunol. 2008; 180:825-32. Study showed essential role of regulatory $\mathrm{CD} 8^{+} \mathrm{T}$ cells during the recovery phase of EAE. [PubMed: 18178821]

81. Mangalam AK, Luckey D, Giri S, et al. Two discreet subsets of CD8 T cells modulate PLP(91110 ) induced experimental autoimmune encephalomyelitis in HLA-DR3 transgenic mice. $\mathrm{J}$ Autoimmun. 2012; 38:344-53. [PubMed: 22459490]

82. Dhib-Jalbut S. Glatiramer acetate (Copaxone) therapy for multiple sclerosis. Pharmacol Ther. 2003; 98:245-55. [PubMed: 12725872]

83. Karandikar NJ, Crawford MP, Yan X, et al. Glatiramer acetate (Copaxone) therapy induces CD8(+) T cell responses in patients with multiple sclerosis. J Clin Invest. 2002; 109:641-9. [PubMed: 11877472]

84. Tennakoon DK, Mehta RS, Ortega SB, et al. Therapeutic induction of regulatory, cytotoxic CD8+ T cells in multiple sclerosis. J Immunol. 2006; 176:7119-29. [PubMed: 16709875]

85. Biegler BW, Yan SX, Ortega SB, et al. Glatiramer acetate (GA) therapy induces a focused, oligoclonal CD8+ T-cell repertoire in multiple sclerosis. J Neuroimmunol. 2006; 180:159-71. [PubMed: 16935352]

86. Feger U, Tolosa E, Huang YH, et al. HLA-G expression defines a novel regulatory T-cell subset present in human peripheral blood and sites of inflammation. Blood. 2007; 110:568-77. [PubMed: 17371944]

87. Airas L, Nikula T, Huang YH, et al. Postpartum-activation of multiple sclerosis is associated with down-regulation of tolerogenic HLA-G. J Neuroimmunol. 2007; 187:205-11. [PubMed: 17561269]

88. Correale J, Villa A. Isolation and characterization of CD8+ regulatory T cells in multiple sclerosis. J Neuroimmunol. 2008; 195:121-34. [PubMed: 18234356]

89. Correale J, Villa A. Role of CD8+ CD25+ Foxp3+ regulatory T cells in multiple sclerosis. Ann Neurol. 2010; 67:625-38. [PubMed: 20437560]

90. Hu D, Weiner HL, Ritz J. Identification of Cytolytic CD161(-)CD56(+) Regulatory CD8 T Cells in Human Peripheral Blood. PLoS One. 2013; 8:e59545. [PubMed: 23527216]

91. Huber M, Heink S, Grothe H, et al. A Th17-like developmental process leads to CD8(+) Tc17 cells with reduced cytotoxic activity. Eur J Immunol. 2009; 39:1716-25. [PubMed: 19544308]

92. Langrish CL, Chen Y, Blumenschein WM, et al. IL-23 drives a pathogenic T cell population that induces autoimmune inflammation. J Exp Med. 2005; 201:233-40. [PubMed: 15657292]

93. Komiyama Y, Nakae S, Matsuki T, et al. IL-17 plays an important role in the development of experimental autoimmune encephalomyelitis. J Immunol. 2006; 177:566-73. [PubMed: 16785554]

94. Matusevicius D, Kivisakk P, He B, et al. Interleukin-17 mRNA expression in blood and CSF mononuclear cells is augmented in multiple sclerosis. Mult Scler. 1999; 5:101-4. [PubMed: 10335518]

95*. Tzartos JS, Friese MA, Craner MJ, et al. Interleukin-17 production in central nervous systeminfiltrating T cells and glial cells is associated with active disease in multiple sclerosis. Am J Pathol. 2008; 172:146-55. One of the first studies to demonstrate the existence of pathogenic IL-17-secreting $\mathrm{CD}^{+}{ }^{+}$T cells. [PubMed: 18156204] 
96. Vanden Eijnden S, Goriely S, De Wit D, et al. IL-23 up-regulates IL-10 and induces IL-17 synthesis by polyclonally activated naive T cells in human. Eur J Immunol. 2005; 35:469-75. [PubMed: 15682457]

97. Acosta-Rodriguez EV, Rivino L, Geginat J, et al. Surface phenotype and antigenic specificity of human interleukin 17-producing T helper memory cells. Nat Immunol. 2007; 8:639-46. [PubMed: 17486092]

98. Li Y, Chu N, Hu A, et al. Increased IL-23p19 expression in multiple sclerosis lesions and its induction in microglia. Brain. 2007; 130:490-501. [PubMed: 17003070]

99. Beriou G, Costantino CM, Ashley CW, et al. IL-17-producing human peripheral regulatory T cells retain suppressive function. Blood. 2009; 113:4240-9. [PubMed: 19171879]

100. Annibali V, Ristori G, Angelini DF, et al. CD161(high)CD8+T cells bear pathogenetic potential in multiple sclerosis. Brain. 2011; 134:542-54. [PubMed: 21216829]

101. Reboldi A, Coisne C, Baumjohann D, et al. C-C chemokine receptor 6-regulated entry of TH-17 cells into the CNS through the choroid plexus is required for the initiation of EAE. Nat Immunol. 2009; 10:514-23. [PubMed: 19305396]

102. Kappos L, Antel J, Comi G, et al. Oral fingolimod (FTY720) for relapsing multiple sclerosis. N Engl J Med. 2006; 355:1124-40. [PubMed: 16971719]

103. Polman CH, O'Connor PW, Havrdova E, et al. A randomized, placebo-controlled trial of natalizumab for relapsing multiple sclerosis. N Engl J Med. 2006; 354:899-910. [PubMed: 16510744]

104. Friese MA, Fugger L. Pathogenic CD8(+) T cells in multiple sclerosis. Ann Neurol. 2009; 66:132-41. [PubMed: 19743458]

105. Crawford MP, Yan SX, Ortega SB, et al. High prevalence of autoreactive, neuroantigen-specific CD8+ T cells in multiple sclerosis revealed by novel flow cytometric assay. Blood. 2004; 103:4222-31. [PubMed: 14976054]

106. Zang YC, Li S, Rivera VM, et al. Increased CD8+ cytotoxic T cell responses to myelin basic protein in multiple sclerosis. J Immunol. 2004; 172:5120-7. [PubMed: 15067096]

107. Hemmer B, Vergelli M, Pinilla C, et al. Probing degeneracy in T-cell recognition using peptide combinatorial libraries. Immunol Today. 1998; 19:163-8. [PubMed: 9577092]

108. Linda H, von Heijne A, Major EO, et al. Progressive multifocal leukoencephalopathy after natalizumab monotherapy. N Engl J Med. 2009; 361:1081-7. [PubMed: 19741229] 


\section{Highlights}

- $\mathrm{CD} 8^{+} \mathrm{T}$ cells outnumber $\mathrm{CD} 4^{+} \mathrm{T}$ cells in MS lesions and can cause damage to all CNS cells

- MHC class I genes may confer risk or protection from MS

- $\mathrm{CD}^{+} \mathrm{T}$ cells induce injury in EAE and virus-induced animal models of demyelinating disease

- $\mathrm{CD}^{+} \mathrm{T}$ cells have a regulatory role in animal models and human MS

- $\mathrm{CD} 8^{+} \mathrm{T}$ cells can secrete IL-17, which may cause damage in MS Lesions 

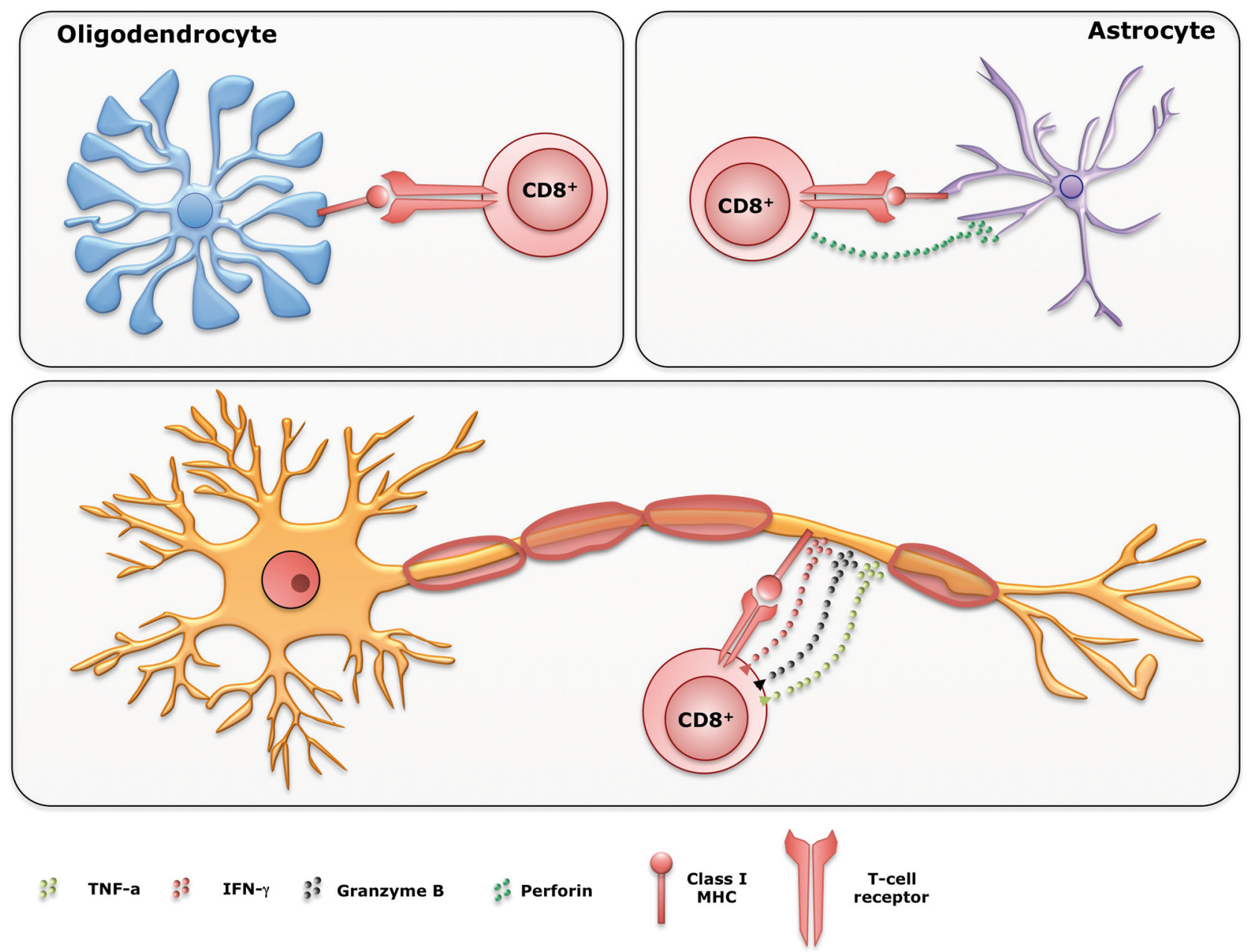

Figure 1. $\mathrm{CDB}^{+} \mathrm{T}$ cells can kill all $\mathrm{CNS}$ cell types

+ T cells can mediate pathology in MS lesions by killing all cell types in the CNS. Under inflammatory conditions, astrocytes, oligodendrocytes, and neurons/axons express MHC Class I molecules and can be recognized and killed by cytotoxic $\mathrm{CD} 8^{+} \mathrm{T}$ cells. Upon recognition of MHC Class I, CD8 ${ }^{+} \mathrm{T}$ cells in a polarized manner, release granules containing perforin and/or granzyme B, molecules that have cytolitic effect on a target cell. In addition, in the inflammatory setting IFN- $\gamma$ and TNF- $\alpha$ are also released, affecting the homeostasis of the neurons and axons that express their corresponding receptors, leading them to apoptosis. 


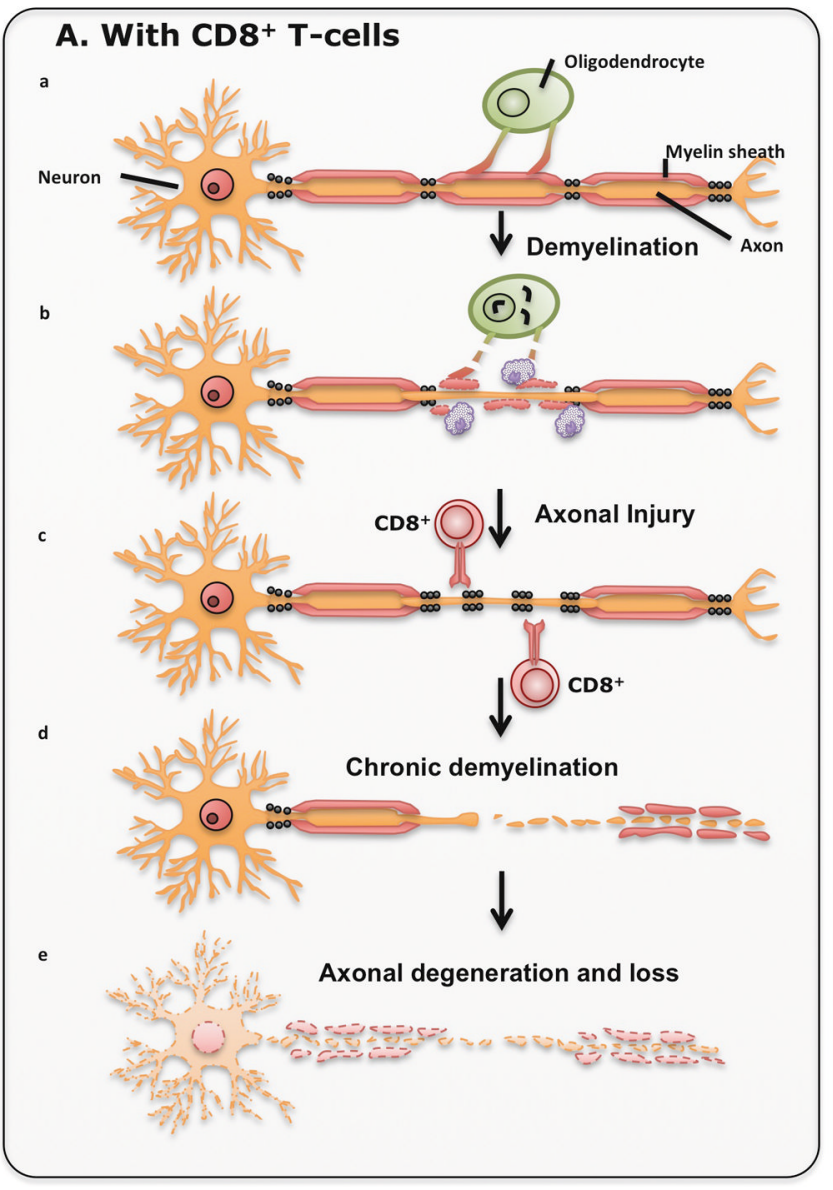

\section{B. Without CD8 ${ }^{+} \mathrm{T}$-cells}

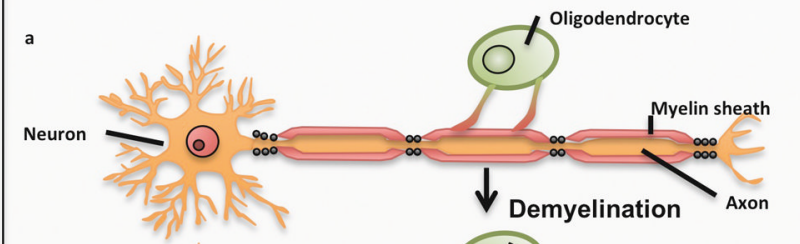

b

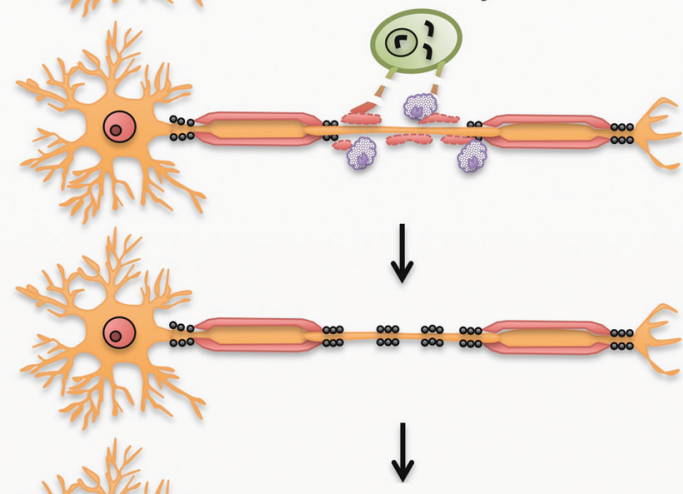

d

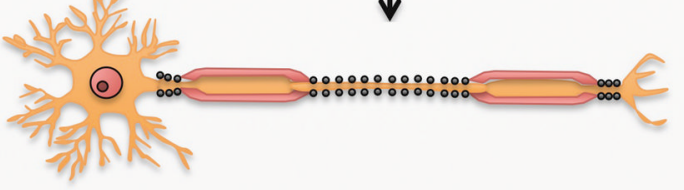

Na-channel redistribution, axonal and functional preservation, and increased potential for remyelination

Figure 2. $\mathrm{CDB}^{+} \mathrm{T}$ cells are responsible for axonal loss and clinical deficits

A) Regardless of the initial trigger that causes demyelination, $\mathrm{CD} 8^{+} \mathrm{T}$ cells induce injury to axons, lead to progressive axonal loss in the environment with bare, unprotected axons due to the chronic demyelination. B) When $\mathrm{CD}^{+} \mathrm{T}$ cells are absent, demyelination may still occur, but due to sodium channel redistribution there is relative preservation of axons, functional preservation and increased potential for remyelination. 
A. Direct regulatory role by cytotoxic killing of self-reactive $\mathrm{CD}^{+}{ }^{+} \mathrm{T}$-cells

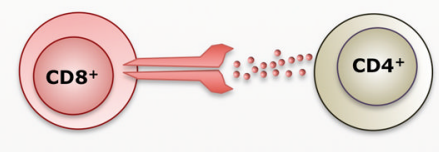

\section{B. Indirect regulatory role through APCs}

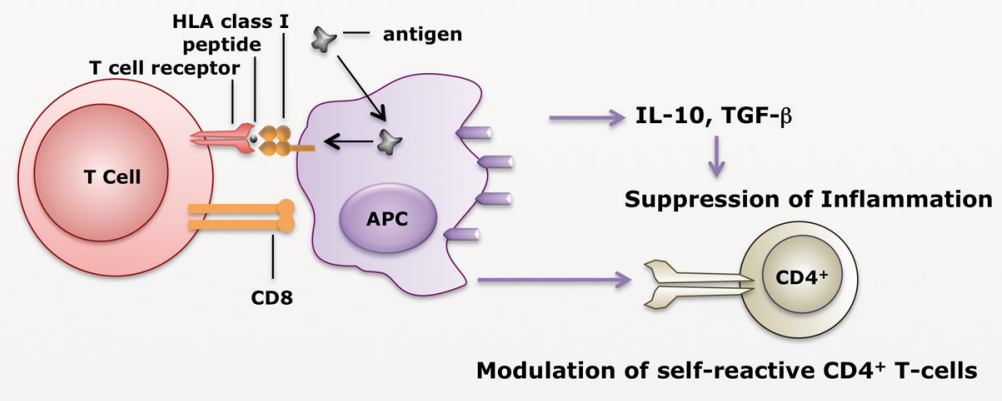

Figure 3. Mechanisms of Regulatory $\mathrm{CD8}^{+} \mathrm{T}$ cell-mediated suppression of disease

A) In the direct mechanism, $\mathrm{CD}^{+} \mathrm{T}$ cells exert direct cytotoxic role by recognizing classical Class I molecule or non-classical HLA-E molecule on CD4 ${ }^{+} \mathrm{T}$ cells. [84] B) CD8 ${ }^{+} \mathrm{T}$ cells may indirectly suppress inflammation by acting through antigen presenting cells (APCs). APCs then secrete anti-inflammatory cytokines IL-10 or TGF- $\beta$, or modulate self-reactive CD4 ${ }^{+} \mathrm{T}$ cells. 


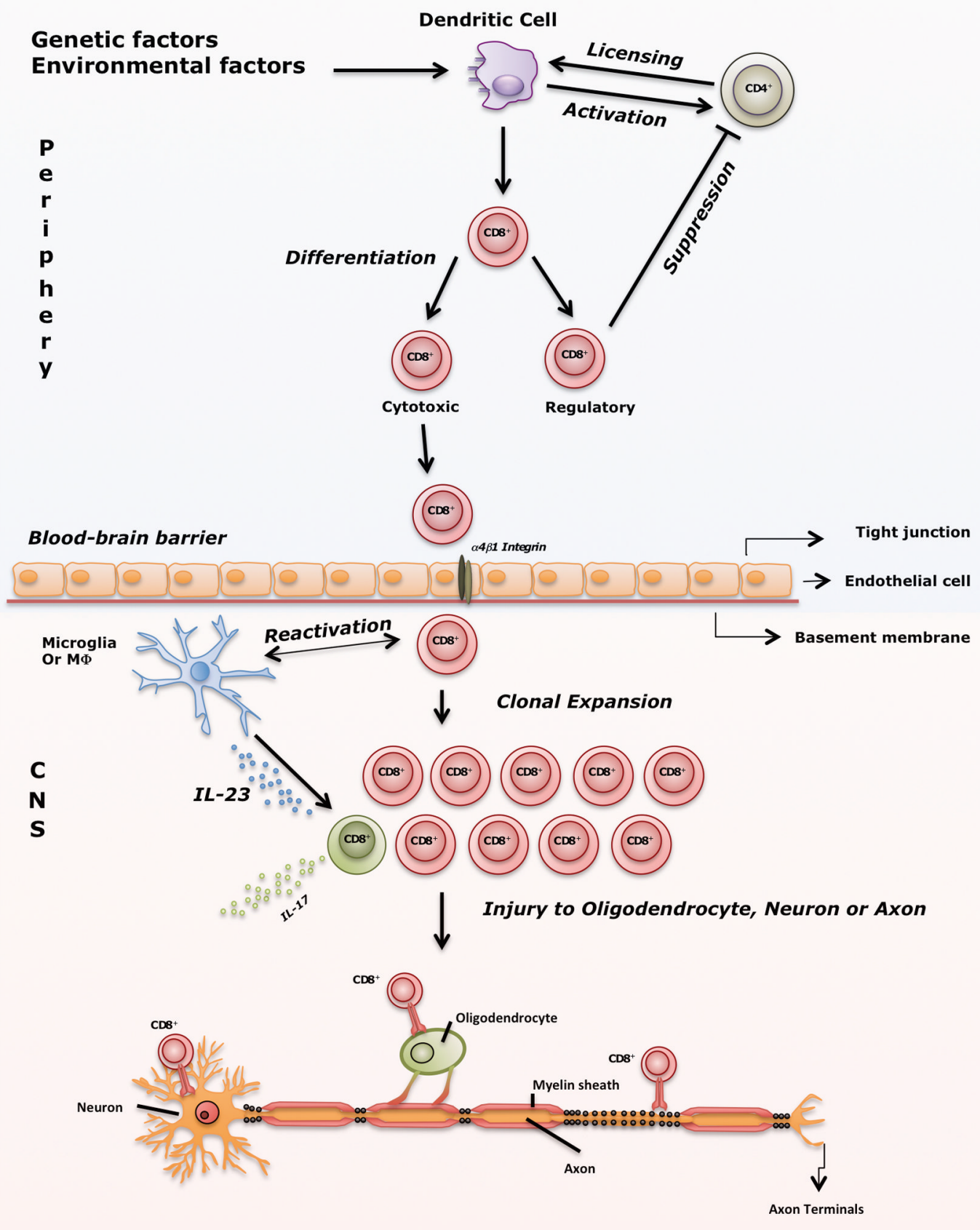

Figure 4. From unknown trigger to CNS injury; a summarized view of the role of $\mathrm{CD8}^{+} \mathrm{T}$ cells in MS pathogenesis

Several environmental factors in combination with genetic factors activate dendritic cells (DCs), which then present epitopes and influence priming of $\mathrm{CD}^{+} \mathrm{T}$ cells. Subsequently, primed $\mathrm{CD}^{+} \mathrm{T}$ cells license $\mathrm{DC}$ s to activate $\mathrm{CD}^{+} \mathrm{T}$ cells by cross-presenting epitopes. Activated $\mathrm{CD}^{+} \mathrm{T}$ cells then differentiate into cytotoxic (CTL) and regulatory cells. Under normal conditions, regulatory $\mathrm{CD}^{+} \mathrm{T}$ cells prevent immune response against self-antigens as shown in Figure 3. However, when this protective mechanism fails autoreactive CTLs migrate through blood-brain barrier with the help of a $4 \beta 1$ integrin (molecular target of natalizumab). Within the CNS, resident microglia or macrophages that express co- 
stimulatory and MHC class I molecules likely are involved in reactivation of $\mathrm{CD} 8^{+} \mathrm{T}$ cells. As a result of reactivation, $\mathrm{CD} 8^{+} \mathrm{T}$ cells clonally expand, meet hypothetical target antigens presented on MHC class I on neurons, axons or oligodendrocyte and induce injury. In the inflammatory milieu of an MS lesion, IL- 6 and IL-1 $\beta$ as well as IL-23 produced by macrophages, polarize some $\mathrm{CD} 8^{+} \mathrm{T}$ cells into IL-17-secreting cells which can comprise up to $10 \%$ of all $\mathrm{CD}^{+} \mathrm{T}$ cells detected in MS lesions. Thus, $\mathrm{CD} 8^{+} \mathrm{IL}-17$-secreting $\mathrm{T}$ cells may influence exacerbations in MS. 


\section{Table 1}

Additive effect of MHC class I alleles with MHC class II alleles [50-52]

\begin{tabular}{ll}
\hline MHC Allele & Odds Ratio \\
\hline HLA-A*0201 & $0.52-0.7$ \\
HLA-A*0301 & $1.9-2.1$ \\
HLA-B*0702 & $1.6-2.2$ \\
HLA-DRB1*1501 & $2.9-3.6$ \\
HLA-DRB1*1501 + HLA-A*0201 & 1.5 \\
HLA-DRB1*1501 + HLA-A*0301 & $3.7-5.2$ \\
HLA-DRB1*1501 + HLA-B*0702 & 3.2 \\
\hline
\end{tabular}

MHC - Major histocompatibility complex 
Table 2

Summary of Regulatory $\mathrm{CD} 8^{+} \mathrm{T}$ cells in EAE.

\begin{tabular}{ll}
\hline Cell Marker & Function \\
\hline $\mathrm{CD}^{+} / \mathrm{CD} 28^{-}$ & Suppression of autoimmunity and clinical deficits [75] \\
$\mathrm{CD}^{+} / \mathrm{LAP}^{+}$ & Ameliorate severity of EAE [79] \\
$\mathrm{CD} 8^{+} / \mathrm{CD} 122^{+}$ & Regulatory role during recovery of EAE [80, 81] \\
\hline
\end{tabular}

EAE - Experimental autoimmune encephalomyelitis 


\section{Table 3}

Summary of Regulatory CD8 ${ }^{+} \mathrm{T}$ cells in Human MS

\begin{tabular}{ll}
\hline Cell Marker & Function \\
\hline $\mathrm{CD} 94 / \mathrm{NKG} 2 \mathrm{~A}$ & Limited suppressive activity of $\mathrm{CD} 8^{+} \mathrm{T}$ cells [88] \\
$\mathrm{CD}^{+} / \mathrm{CD} 25^{+} / \mathrm{FoxP}^{+}$ & Suppressed secretion of IFN- $\gamma$ and IL-17, and proliferation of autoreactive CD4 ${ }^{+} \mathrm{T}$ cells [89] \\
$\mathrm{CD}{ }^{+} / \mathrm{CD} 161^{-} / \mathrm{CD} 56^{+}$ & Lysed TCR-activated $\mathrm{CD} 4^{+} \mathrm{T}$ cells in vitro [90] \\
\hline
\end{tabular}

MS - Multiple sclerosis 